\title{
ERYTHROPOIETIN IN THE EVALUATION OF TREATMENT OUTCOMES IN PATIENTS WITH POLYTRAUMA
}

\author{
Vladimir Arsenijević ${ }^{1}$, Ana Šijački ${ }^{1,2}$, Ivan Marjanović ${ }^{1}$, Dušan Micić ${ }^{1}$, Vladimir Nikolić2, \\ Aleksandar Veljković ${ }^{3}$, Pavle Popović ${ }^{1}$, Sanja Stanković ${ }^{4}$ and Vasilije Jeremić ${ }^{1,2}$
}

${ }^{1}$ Clinical Department of Emergency Surgery, Emergency Center, Clinical Centre of Serbia, Belgrade, Serbia; ${ }^{2}$ School of Medicine, University of Belgrade, Belgrade, Serbia; ${ }^{3}$ Faculty of Mathematics, University of Belgrade, Belgrade, Serbia; ${ }^{4}$ Center of Medical Biochemistry, Clinical Centre of Serbia, Belgrade, Serbia

SUMMARY - Polytrauma is a term describing patients with injuries involving multiple body regions that compromises function of the body and/or organ involved. The aim of the study was to evaluate the potential role of erythropoietin in predicting poorer outcome in trauma patients. This prospective study included 86 patients admitted to the Emergency Center of Serbia due to polytrauma assigned according to Injury Severity Score (ISS). The patients were further evaluated using the Acute Physiology and Chronic Health Evaluation II and Sequential Organ Failure Assessment scores and erythropoietin levels. There was a significant difference among erythropoietin levels at admission, after 48 and 72 hours, and on day 7 of hospital stay, with significantly higher levels in patients with ISS values 49-75. Based on the results, ROC curves were used to identify cut-off levels to predict ISS score with critical clinical course. It was concluded that erythropoietin could be a good marker of injury severity. Further research has to be performed to determine the cut-off values of erythropoietin that are significant for injury severity.

Key words: Multiple injuries - therapy; Erythropoietin - therapeutic use; Treatment outcome

\section{Introduction}

Patients with polytrauma are one of the greatest challenges faced by physicians ${ }^{1}$. Polytrauma is a term describing patients with multiple injuries that involve several parts of the body and compromise function of the body and/or organ involved ${ }^{1-3}$. The most popular and most commonly used definition of trauma is based on the Injury Severity Score (ISS) ${ }^{2,4,5}$. Another definition that is also appropriate describes it as injury to at least two body regions with Abbreviated Injury Scale (AIS) $\geq 3$ and with the presence of systemic inflammatory response syndrome (SIRS) on at least one day

Correspondence to: Vladimir Arsenijević, $M D$, Clinic for Emergency Surgery, Clinical Centre of Serbia, Pasterova 2, 11000 Belgrade, Serbia

E-mail: vlada.dr.ars@gmail.com

Received June 19, 2017, accepted November 14, 2017 during the first 72 hours ${ }^{1,5}$. Appropriate triage and optimization of treatment approach in such patients is one of the key factors that influence final outcome in these patients ${ }^{1,6,7}$. Treatment of patients with polytrauma requires plenty of resources and effort, multiple surgeries, prolonged stay at intensive care unit, and complex rehabilitation programs ${ }^{1,2,7}$. Mortality in patients with polytrauma varies from $9 \%$ to $48 \%$, depending on age group, extent of injuries, other comorbidities, and appropriate triage $e^{5,6,8-10}$.

Furthermore, it is very important to timely evaluate treatment outcome in patients with polytrauma ${ }^{5}$. As of today, many prognostic factors have been developed ${ }^{5}$. Erythropoietin, a glycoprotein predominantly synthesized in the kidneys, plays the central role in stimulation of erythropoiesis, but also has other purposes, such as cytoprotective, anti-apoptotic, anti-inflammatory and antioxidant activity ${ }^{11,12}$. Studies have shown 
that the administration of erythropoietin before or after stressful event that led to cell ischemia protects cells from development of ischemic sequels ${ }^{13}$. Erythropoietin has a vast therapeutic potential in patients with polytrauma. Studies have shown that the use of erythropoietin is useful in posttraumatic anemia triggered by systemic inflammatory response that is present in polytrauma ${ }^{14}$. Also, therapeutic properties of erythropoietin have already been used in septic shock, endotoxemia, hemorrhagic shock, spinal cord trauma and multiple organ trauma ${ }^{15}$.

\section{Patients and Methods}

This prospective study included patients admitted to the Emergency Center, Clinical Center of Serbia during the period from October 2016 to March 2017 because of polytrauma. Polytrauma was defined based on the ISS score ${ }^{4}$. In order to consider critical patients only, the study included patients with ISS score 25 or higher ${ }^{16}$. The study included a total of 86 patients who were further assigned to one of two groups: group 1 with ISS score 25-48 and group 2 with ISS score 49$75^{16}$. The exclusion criteria were pregnancy, treatment with erythropoietin products, hematologic condition, malignant diseases, and failure to obtain consent for participation in the study. The following clinical variables were collected: age, sex, cause of injury, preexisting chronic disease, length of hospital stay, outcome, blood pressure, mean arterial pressure (MAP), heart rate, body temperature, respiratory rate, $\mathrm{SpO}_{2} / \mathrm{FiO}_{2} \mathrm{ra}^{-}$ tio, neurologic status (Glasgow Coma Scale, GCS), as well as the amount of transfusions administered to the patient. The causes of injury covered by the study were traffic injuries, fall from height, and other (including firearm injuries and explosions). Prior chronic conditions were divided into 5 groups: heart failure, liver cirrhosis, epilepsy, renal failure and angina pectoris.

The length of hospital stay was classified into two groups: up to 7 days and more than 7 days. At admission, on day 2, day 3 and day 7, all patients underwent laboratory evaluation using the following tests: white blood cell count (WBC), platelet count, hematocrit, aspartate aminotransferase (AST), alanine aminotransferase (ALT), gamma-glutamyltransferase (GGT), serum electrolyte levels, creatinine, international normalized ratio (INR), prothrombin time, albumin, $\mathrm{C}$-reactive protein (CRP), venous lactate and total bilirubin.
Furthermore, erythropoietin levels were measured at admission, 24 and 72 hours following admission, and on day 7. The patients were further evaluated based on the Acute Physiology and Chronic Health Evaluation II (APACHE II) and Sequential Organ Failure Assessment (SOFA) scores that were calculated at admission and on days 2, 3 and 7. APACHE II score was calculated from the patient's age and the following 12 parameters: $\mathrm{PaO}_{2}$, temperature, MAP, arterial $\mathrm{pH}$, heart rate, respiratory rate, sodium, potassium, creatinine, hematocrit, leukocyte count and $\mathrm{GCS}^{17}$. Information regarding previous health status, including prior surgeries, history of organ insufficiency or immunocompromised state, was calculated into the re$\operatorname{sult}^{17}$. The conventional SOFA score was calculated using the peripheral arterial oxygen saturation $\left(\mathrm{SpO}_{2}\right)$ to $\mathrm{FiO}_{2}$ ratio $\left(\mathrm{SpO}_{2} / \mathrm{FiO}_{2}\right)^{18}$. The evaluation was also performed based on erythropoietin levels in group 1 and 2 patients. Furthermore, we calculated cut-off levels of erythropoietin in predicting higher ISS score, i.e. in predicting which patients had more complicated polytrauma and required additional resources and care during their further treatment.

Statistical analyses were performed using the SPSS 22.0 (SPSS Inc., Chicago, IL, USA) software. This study protocol complied with ethical principles of the Declaration of Helsinki of 1975, as revised in 1983, and was approved by the Ethics Committee of the Clinical Center of Serbia. For normal variables, means and standard deviations were calculated. $\chi^{2}$ test and independent sample $t$-test were used to assess differences

\section{Table 1. Patient demographic characteristics}

\begin{tabular}{|l|l|l|}
\hline \multicolumn{2}{|l|}{ Total number of patients } & 86 \\
\hline \multirow{2}{*}{ Sex: } & Male & $64(74.4 \%)$ \\
& Female & $22(25.6 \%)$ \\
\hline \multirow{2}{*}{ Age (yrs) } & & $48.1 \pm 19.6$ \\
& & $(\min 16 ; \max 88)$ \\
\hline \multirow{2}{*}{ Cause } & Traffic accident & $54(62.8 \%)$ \\
of injury: & Fall from height & $26(30.2 \%)$ \\
& Other & $6(7 \%)$ \\
\hline \multirow{4}{*}{$\begin{array}{l}\text { Prior chronic } \\
\text { condition: }\end{array}$} & Heart failure & $12(60 \%)$ \\
& Liver cirrhosis & $2(10 \%)$ \\
& Epilepsy & $2(10 \%)$ \\
& Renal failure & $2(10 \%)$ \\
& Angina pectoris & $2(10 \%)$ \\
\hline
\end{tabular}


Table 2. Patient clinical characteristics

\begin{tabular}{|l|l|l|}
\hline $\begin{array}{l}\text { Duration of } \\
\text { hospitalization }\end{array}$ & $\begin{array}{l}\text { Up to 7 days } \\
\text { More than 7 days }\end{array}$ & $\begin{array}{l}16(34.8 \%) \\
30(65.2 \%)\end{array}$ \\
\hline \multirow{2}{*}{ Outcome: } & Fatal outcome & $8(10.5 \%)$ \\
& Survivors & $68(89.5 \%)$ \\
\hline ISS & Day 1 & $40.5 \pm 12.8$ \\
\hline \multirow{5}{*}{ APACHE II } & Day 2 & $18.9 \pm 10.9$ \\
& Day 3 & $18.9 \pm 14.1$ \\
& Day 7 & $17.8 \pm 12.6$ \\
\hline \multirow{5}{*}{ SOFA } & Day 1 & $14.1 \pm 5.9$ \\
& Day 2 & $12.9 \pm 3.5$ \\
& Day 3 & $12.9 \pm 3.4$ \\
& Day 7 & $11.1 \pm 2.1$ \\
\hline \multirow{5}{*}{ Erythropoietin } & Admission & $43.1 \pm 46.3$ \\
& $24 \mathrm{~h}$ & $44.7 \pm 76.9$ \\
& $48 \mathrm{~h}$ & $22.9 \pm 38.8$ \\
& $72 \mathrm{~h}$ & $18.6 \pm 30.6$ \\
\hline Transfusion & Day 7 & $8.4 \pm 8.7$ \\
\hline
\end{tabular}

ISS = Injury Severity Score; APACHE II = Acute Physiology and Chronic Health Evaluation II; SOFA = Sequential Organ Failure Assessment between the groups. The values of $\mathrm{p}<0.05$ were considered statistically significant. The performance of erythropoietin in predicting higher ISS score was analyzed by calculating area under the receiver operating characteristics curves (AUROC). The best cut-off points were identified based on the ROC curves.

\section{Results}

Tables 1 and 2 show demographic and clinical characteristics of patients. The study included $86 \mathrm{pa}-$ tients. There were three times more male than female patients $(74.4 \%$ vs. $25.6 \%)$. The patient mean age was 48 , range $16-88$ years. The most common cause of injury was traffic accident accounting for $62.8 \%$ of patients. Among prior chronic conditions, heart failure was common $(n=12)$. In most patients, the length of hospital stay was more than 7 days $(65.2 \%)$ and the outstanding majority of patients survived (89.5\%).

Table 2 shows mean ISS, APACHE II and SOFA score and erythropoietin levels. The patients received a mean of $2598.5 \mathrm{~mL}$ of transfusion (Table 2).

Table 3 shows demographic data broken down by patient groups based on ISS score. The mean age in groups 1 and 2 was 50 and 33 years, respectively, and

Table 3. Demographic and clinical data on patients classified into two groups based on the Injury Severity Score (ISS)

\begin{tabular}{|c|c|c|c|c|}
\hline \multicolumn{2}{|l|}{ Parameter } & $\begin{array}{l}\text { Group 1 } \\
\text { (ISS 25-48) }\end{array}$ & $\begin{array}{l}\text { Group 2 } \\
\text { (ISS 49-75) }\end{array}$ & $\mathrm{p}$ value \\
\hline \multicolumn{2}{|l|}{ Age } & $50.8 \pm 19.1$ & $33.0 \pm 16.2$ & 0.003 \\
\hline Sex & $\begin{array}{l}\text { Male } \\
\text { Female }\end{array}$ & $\begin{array}{l}54 \\
20\end{array}$ & $\begin{array}{l}10 \\
2\end{array}$ & 0.445 \\
\hline Length of hospital stay & $\begin{array}{l}\text { Up to } 7 \text { days } \\
\text { More than } 7 \text { days }\end{array}$ & $\begin{array}{l}8 \\
30\end{array}$ & $\begin{array}{l}8 \\
0\end{array}$ & $<0.001$ \\
\hline Outcome & \begin{tabular}{|l|} 
Survivors \\
Fatal outcome
\end{tabular} & $\begin{array}{l}66 \\
0\end{array}$ & $\begin{array}{l}2 \\
8\end{array}$ & $<0.001$ \\
\hline Transfusion & & 4413.3 & 3317.1 & 0.320 \\
\hline
\end{tabular}

Table 4. APACHE II score in group 1 and 2 patients

\begin{tabular}{|l|l|l|l|}
\hline APACHE II score & Group 1 & Group 2 & p value \\
\hline Day 1 & $16.5 \pm 6.8$ & $33.6 \pm 18.7$ & $<0.001$ \\
Day 2 & $16.4 \pm 9.4$ & $34.9 \pm 25.1$ & $<0.001$ \\
Day 3 & $15.3 \pm 8.1$ & $37.1 \pm 22.4$ & $<0.001$ \\
Day 7 & $13.9 \pm 6.1$ & $15.0 \pm 0.0$ & 0.739 \\
\hline
\end{tabular}

APACHE II = Acute Physiology and Chronic Health Evaluation II
Table 5. SOFA score in group 1 and 2 patients

\begin{tabular}{|l|l|l|l|}
\hline SOFA score & Group 1 & Group 2 & p value \\
\hline Day 1 & $12.5 \pm 3.3$ & $15.8 \pm 3.3$ & 0.002 \\
Day 2 & $12.2 \pm 2.8$ & $17.5 \pm 3.8$ & $<0.001$ \\
Day 3 & $11.9 \pm 3.1$ & $18.4 \pm 4.4$ & $<0.001$ \\
Day 7 & $11.0 \pm 2.1$ & $13.5 \pm 1.7$ & 0.022 \\
\hline
\end{tabular}

SOFA = Sequential Organ Failure Assessment 
Table 6. Erythropoietin levels in group 1 and 2 patients

\begin{tabular}{|l|l|l|l|}
\hline Erythropoietin & Group 1 & Group 2 & p value \\
\hline Admission & $32.5 \pm 32.4$ & $100.5 \pm 67.4$ & $<0.001$ \\
$24 \mathrm{~h}$ & $39.3 \pm 76.4$ & $69.3 \pm 64.3$ & 0.204 \\
$48 \mathrm{~h}$ & $15.5 \pm 27.2$ & $56.8 \pm 64.5$ & 0.001 \\
$72 \mathrm{~h}$ & $12.7 \pm 20.3$ & $46.2 \pm 52.4$ & $<0.001$ \\
Day 7 & $7.1 \pm 8.1$ & $16.4 \pm 8.4$ & 0.001 \\
\hline
\end{tabular}

Table 7. Cut-offlevels with sensitivity, specificity and $A U R O C$ values

\begin{tabular}{|l|l|l|l|l|}
\hline $\begin{array}{l}\text { Erythro- } \\
\text { poietin }\end{array}$ & $\begin{array}{l}\text { Cut-off } \\
\text { level }\end{array}$ & Sensitivity & Specificity & AUROC \\
\hline Admission & 42.3 & $80 \%$ & $81.8 \%$ & 0.836 \\
$48 \mathrm{~h}$ & 11.9 & $100 \%$ & $72.7 \%$ & 0.895 \\
$72 \mathrm{~h}$ & 11.3 & $100 \%$ & $71.8 \%$ & 0.923 \\
Day 7 & 8.3 & $100 \%$ & $71.8 \%$ & 0.891 \\
\hline
\end{tabular}

AUROC $=$ area under the receiver operating characteristics curve

the difference between the two groups was significant $(\mathrm{p}=0.003)$. Group 1 had more patients who stayed at the hospital for more than 7 days $(\mathrm{p}<0.001)$. The number of patients who survived was significantly higher in group 1 than in group 2 (66 vs. 2), yielding a highly significant difference $(\mathrm{p}<0.001)$.

APACHE II scores measured on days 1, 2 and 3 were significantly higher in group $2(\mathrm{p}<0.001)$, as illustrated in Table 4.

SOFA score calculated on days 1,2,3 and 7 of hospital stay was significantly higher in group 2 (Table 5).

There was a significant difference between erythropoietin levels at admission, after 48 and 72 hours, and on day 7 of hospital stay. Significantly higher levels were found in group 2, as shown in Table 6 .

Based on significantly higher erythropoietin levels recorded in group 2, we plotted ROC curves that were further used to identify the cut-off levels to predict ISS score of 48-75 (Fig. 1). Table 7 shows erythropoietin cut-off levels, together with sensitivity and specificity, as well as AUROC values.

\section{Discussion}

The term "polytrauma" signifies injuries to at least two body regions that are life-threatening ${ }^{1}$. In the $<40$ age group, its incidence is $44.9 \%$ and it is the most
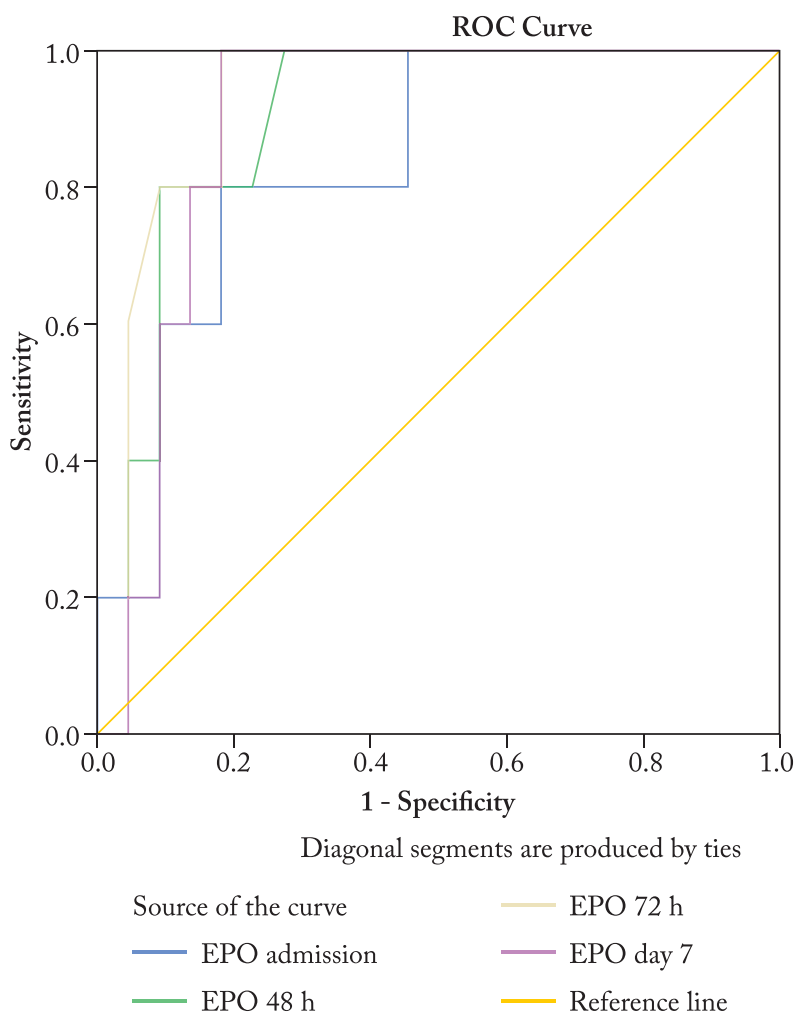

Fig. 1. Receiver operator curve (ROC).

$\mathrm{EPO}=$ erythropoietin

common cause of death. The mortality and morbidity rates and functional recovery are directly affected by professional and timely care ${ }^{2,3}$. Appropriate triage and optimization of treatment approach in such patients is one of the key factors that affect final outcome in these patients ${ }^{1,6,7}$. Treatment of patients with polytrauma requires plenty of resources and efforts, multiple surgeries, prolonged stay at the intensive care unit, and complex rehabilitation programs considering the course of the disease is complicated by sepsis, anemia and multiorgan dysfunction ${ }^{1,2,7}$.

Our study showed a predominance of male patients ( $74.4 \%$ of males vs. $25.6 \%$ of females), which is in accordance with other studies that examined this subject ${ }^{19-23}$.

The mean age of patients included in this study was 48.1, which is in accordance with the study by Berber et al. ${ }^{24}$, whereas another study conducted by Hyder et al. in Pakistan showed a somewhat younger population with as many as $51.1 \%$ of patients aged from 20 to $39^{23}$. Furthermore, a study by Tosounidis et al. showed the mean patient age of $38.4^{25}$. 
The most common cause of injuries in our study were traffic accidents (62.8\%), while the second most common cause were falls from height (30.2\%). The study by Hyder et al. demonstrated a somewhat lower incidence of traffic injuries (51.1\%) and falls from height $(17.5 \%)^{23}$.

It was observed that heart failure was the most common prior condition in our patients. This fact could be explained by heart failure being a complicated disease with high morbidity and mortality rates, affecting many physical and mental abilities of patients, thus making trauma common in this population ${ }^{26}$.

There were twice more patients who stayed at the hospital for more than 7 days, accounting for $65 \%$ of all patients. Paydar et al. report on average length of hospitalization of 7.4 days, with maximum duration of 21 days $^{27}$. Abedzadeh-Kalahroudi et al. compared the length of hospital stay between a group of patients having returned to their work and a group that could not return to their place of work after trauma. In the group of patients who did return to their place of work after trauma, most of them had the length of hospital stay of 1-6 days. In the other group, hospital stay of more than 6 days prevailed ${ }^{28}$.

The mean ISS score in patients from our study was 40.5 , signifying that the majority of patients had complicated polytrauma and that these patients were most commonly in severe condition and required extensive efforts for their treatment, both in terms of resources and staff ${ }^{16}$.

The mean volume of transfusion received by the patients was $2598.5 \mathrm{~mL}$. Optimal timing and volume of transfusion is difficult to determine, but it is something that a clinician should always bear in mind because studies have shown that the larger the volume of transfusion, the higher is the likelihood of some of the transfusion related adverse sequels, such as infection, acute lung injury, acute kidney injury, and thromboembolic events ${ }^{29,30}$. Furthermore, there could be other complications, such as reperfusion injury, vasoconstriction, inflammation, or impaired immune reaction ${ }^{29}$.

Considering demographic and clinical characteristics of patients assigned to different groups based on their ISS score, it is seen that the second group (with more severe injuries) involved younger population, more fatal outcomes and longer hospital stay. Similar results were obtained by Reihani et al., whose study, similar to ours, showed traffic injuries as the major cause of polytrauma and larger proportion of young males with more serious injuries ${ }^{31}$.

Erythropoietin levels at admission, 48 and 72 hours and 7 days following admission were significantly higher in the population of patients with ISS score 49-75. The explanation may lie in the fact that the patients with ISS score 49-75 had severe polytrauma and that they were in very critical condition with multiple injuries, various complications and more severe overall condition compared to patients from the group with ISS score 25-48. Studies performed to date dealing with this subject have shown that many tissues produce and locally release erythropoietin in response to hypoxic, biochemical and physical stress. Erythropoietin protects tissue from ischemia and reperfusion injury, it has antiapoptotic effect and promotes tissue regeneration ${ }^{11-14,32}$. We also used erythropoietin to predict whether the patient would be assigned to group 2 according to ISS score. Erythropoietin proved best at 72 hours following admission, with 11.3 cut-off value, $100 \%$ sensitivity, $71.8 \%$ specificity, and AUROC value of 0.923 .

Following the above mentioned, we conclude that larger amounts of erythropoietin are produced and released in more severely traumatized patients, which should be a subject of further investigations aimed at determining which group of patients would benefit more from treatment with erythropoietin. We also showed that erythropoietin could also have good characteristics in predicting the severity of polytrauma.

Based on the results of our study, we conclude that erythropoietin appears to be a good marker of injury severity. Further research has to be performed to determine the cut-off values of erythropoietin that are significant for injury severity.

\section{References}

1. Butcher N, Balogh ZJ. The definition of polytrauma: the need for international consensus. Injury. 2009;40 Suppl 4:S12-22, doi: 10.1016/j.injury.2009.10.032

2. Follin A, Jacqmin S, Chhor V, Bellenfant F, Robin S, Guinvarc'h A, et al. Tree-based algorithm for prehospital triage of polytrauma patients. Injury. 2016;47(7):1555-61, doi: 10.1016/j. injury.2016.04.024

3. Saad S, Mohamed N, Moghazy A, Ellabban G, El-Kamash S. Venous glucose, serum lactate and base deficit as biochemical predictors of mortality in patients with polytrauma. Ulus Travma Acil Cerrahi Derg. 2016;22(1):29-33, doi: 10.5505/tjtes. 2015.96832 
4. Baker SP, O’Neill B. The injury severity score: an update. J Trauma. 1976;16(11):882-5.

5. Wong TH, Krishnaswamy G, Nadkarni NV, Nguyen HV, Lim $\mathrm{GH}$, Bautista DC, et al. Combining the new injury severity score with an anatomical polytrauma injury variable predicts mortality better than the new injury severity score and the injury severity score: a retrospective cohort study. Scand J Trauma Resusc Emerg Med. 2016;24:25, doi: 10.1186/ s13049-016-0215-6

6. Lovric Z. Definition of polytrauma: discussion on the objective definition based on quantitative estimation of multiply injured patients during wartime. Injury. 2015;46 Suppl 6:S24-6, doi: 10.1016/j.injury.2015.10.048

7. Schweiberer L, Nast-Kolb D, Duswald KH, Waydhas C, Muller K. Polytrauma - treatment by the staged diagnostic and therapeutic plan. Unfallchirurg. 1987;90(12):529-38. (in German). doi: 10.1186/s13049-017-0400-2

8. MacKenzie EJ, Rivara FP, Jurkovich GJ, Nathens AB, Frey KP, Egleston BL, et al. A national evaluation of the effect of trauma-center care on mortality. N Engl J Med. 2006;354(4): 366-78, doi: 10.1056/NEJMsa052049

9. Braun BJ, Holstein J, Fritz T, Veith NT, Herath S, Morsdorf P, et al. Polytrauma in the elderly: a review. EFORT Open Rev. 2016;1(5):146-51, doi: 10.1302/2058-5241.1.160002

10. Champion HR, Copes WS, Sacco WJ, Lawnick MM, Keast SL, Bain LW Jr, et al. The Major Trauma Outcome Study: establishing national norms for trauma care. J Trauma. 1990; 30(11):1356-65.

11. Taguchi K, Yamasaki K, Seo H, Otagiri M. Potential use of biological proteins for liver failure therapy. Pharmaceutics. 2015;7(3):255-74, doi: 10.3390/pharmaceutics7030255

12. Kedarisetty CK, Anand L, Bhardwaj A, Bhadoria AS, Kumar G, Vyas AK, et al. Combination of granulocyte colony-stimulating factor and erythropoietin improves outcomes of patients with decompensated cirrhosis. Gastroenterology. 2015;148(7): 1362-70.e7, doi: 10.1053/j.gastro.2015.02.054

13. Joyeux-Faure M. Cellular protection by erythropoietin: new therapeutic implications? J Pharmacol Exp Ther. 2007;323(3): 759-62, doi: 10.1124/jpet.107.127357.

14. Robinson Y, Hostmann A, Matenov A, Ertel W, Oberholzer A. Erythropoiesis in multiply injured patients. J Trauma. 2006;61(5):1285-91, doi: 10.1097/01.ta.0000240969.13891.9b

15. Thiemermann C. Beneficial effects of erythropoietin in preclinical models of shock and organ failure. Crit Care. 2007; 11(3):132, doi: 10.1186/cc5912

16. Rozenfeld M, Radomislensky I, Freedman L, Givon A, Novikov I, Peleg K. ISS groups: are we speaking the same language? Inj Prev. 2014;20(5):330-5. doi: 10.1136/injuryprev-2013-041042

17. Knaus WA, Draper EA, Wagner DP, Zimmerman JE. APACHE II: a severity of disease classification system. Crit Care Med. 1985;13(10):818-29.

18. Pandharipande PP, Shintani AK, Hagerman HE, St Jacques PJ, Rice TW, Sanders NW, et al. Derivation and validation of
Spo2/Fio2 ratio to impute for $\mathrm{Pao} / \mathrm{Fio} 2$ ratio in the respiratory component of the Sequential Organ Failure Assessment score. Crit Care Med. 2009;37(4):1317-21, doi: 10.1097/ CCM.0b013e31819cefa9

19. Napolitano LM, Greco ME, Rodriguez A, Kufera JA, West RS, Scalea TM. Gender differences in adverse outcomes after blunt trauma. J Trauma. 2001;50(2):274-80.

20. Gannon CJ, Napolitano LM, Pasquale M, Tracy JK, McCarter RJ. A statewide population-based study of gender differences in trauma: validation of a prior single-institution study. J Am Coll Surg. 2002;195(1):11-8.

21. Wohltmann CD, Franklin GA, Boaz PW, Luchette FA, Kearney PA, Richardson JD, et al. A multicenter evaluation of whether gender dimorphism affects survival after trauma. Am J Surg. 2001;181(4):297-300.

22. Croce MA, Fabian TC, Malhotra AK, Bee TK, Miller PR. Does gender difference influence outcome? J Trauma. 2002; 53(5):889-94, doi: 10.1097/01.TA.0000031173.43215.EE

23. Hyder AA, He S, Zafar W, Mir MU, Razzak JA. One hundred injured patients a day: multicenter emergency room surveillance of trauma in Pakistan. Public Health. 2017;148:88-95, doi: 10.1016/j.puhe.2017.03.006

24. Berber O, Vasireddy A, Nzeako O, Tavakkolizadeh A. The highrisk polytrauma patient and inferior vena cava filter use. Injury. 2017;48(7):1400-1404, doi: 10.1016/j.injury.2017.04.038

25. Tosounidis TH, Sheikh HQ, Kanakaris NK, Giannoudis PV. The use of external fixators in the definitive stabilisation of the pelvis in polytrauma patients: safety, efficacy and clinical outcomes. Injury. 2017;48(6):1139-46, doi: 10.1016/j.injury. 2017.03.033

26. Gelfman LP, Kavalieratos D, Teuteberg WG, Lala A, Goldstein NE. Primary palliative care for heart failure: what is it? How do we implement it? Heart Fail Rev. 2017;22(5):611-620, doi: 10.1007/s10741-017-9604-9

27. Paydar S, Kabiri H, Barhaghtalab M, Ghaffarpasand F, Safari S, Baratloo A. Hemodynamic changes following routine fluid resuscitation in patients with blunt trauma. Trauma Mon. 2016;21(4):e23682, doi: 10.5812/traumamon.23682

28. Abedzadeh-Kalahroudi M, Razi E, Sehat M, Asadi-Lari M. Return to work after trauma: a survival analysis. Chin J Traumatol. 2017;20(2):67-74, doi: 10.1016/j.cjtee.2016.03.008

29. Jones AR, Frazier SK. Consequences of transfusing blood components in patients with trauma: a conceptual model. Crit Care Nurse. 2017;37(2):18-30, doi: 10.4037/ccn2017965

30. Holcomb JB. Optimal use of blood products in severely injured trauma patients. Hematology Am Soc Hematol Educ Program.2010;2010:465-9,doi: 10.1182/asheducation-2010.1.465

31. Reihani H, Pirazghandi H, Bolvardi E, Ebrahimi M, Pishbin $\mathrm{E}$, Ahmadi $\mathrm{K}$, et al. Assessment of mechanism, type and severity of injury in multiple trauma patients: a cross sectional study of a trauma center in Iran. Chin J Traumatol. 2017;20(2):75-80, doi: 10.1016/j.cjtee.2016.02.004

32. Nekoui A, Blaise G. Erythropoietin and nonhematopoietic effects. Am J Med Sci. 2017;353(1):76-81, doi: 10.1016/ j.amjms.2016.10.009 
Sažetak

\title{
ERITROPOETIN U PROCJENI ISHODA LIJEČENJA KOD BOLESNIKA S POLITRAUMOM
}

\author{
V. Arsenijević, A. Šijački, I. Marjanović, D. Micić, V. Nikolić, A. Veljković, P. Popović, S. Stanković i V. Jeremić
}

Politrauma je termin koji opisuje bolesnike s povredama koje uključuju više dijelova tijela i koje ugrožavaju funkciju tijela i/ili organa. Cilj studije je bio procijeniti potencijalnu ulogu eritropoetina u predviđanju lošeg ishoda kod bolesnika s politraumom. Ova prospektivna studija obuhvatila je 86 bolesnika koji su primljeni u Urgentni centar Srbije zbog politraume dijagnosticirane prema rezultatu težine povreda (Injury Severity Score, ISS). Bolesnici su dalje procijenjeni pomoću rezultata A kutnog fiziološkog bodovnog sustava i bodovnog sustava kronične procjene zdravlja II. te procjene insuficijencije organa i razine eritropoetina. Postojala je značajna razlika između razine eritropoetina kod prijma, poslije 48 i 72 sata te sedmog dana boravka u bolnici, sa znatno višim razinama kod bolesnika s vrijednostima ISS 49-75. Na osnovi rezultata krivulje ROC su primijenjene za identifikaciju graničnih vrijednosti kako bi se predvidio rezultat ISS s kritičnim kliničkim tijekom. Zaključeno je da eritropoetin može biti dobar pokazatelj ozbiljnosti povreda. Potrebno je daljnje istraživanje za određivanje graničnih vrijednosti eritropoetina koje su značajne za ozbiljnost povreda.

Ključne riječi: Politrauma - terapija; Eritropoetin - terapijska primjena; Ishod liječenja 